\title{
Perspectives of Elementary School Teachers on Outdoor Education
}

\author{
Ozcan Palavan $^{1}$, Volkan Cicek ${ }^{2, *}$, Merve Atabay ${ }^{1}$ \\ ${ }^{1}$ College of Education, Zirve University, Turkey \\ ${ }^{2}$ College of Education, International Zaman University, Cambodia
}

Copyright $\bigcirc 2016$ by authors, all rights reserved. Authors agree that this article remains permanently open access under the terms of the Creative Commons Attribution License 4.0 international License.

\begin{abstract}
Outdoor education stands out as one of the methods to deliver the desired educational outcomes taking the needs of the students, teachers and the curricular objectives into consideration. Outdoor education focuses on experimental, hands-on learning in real-life environments through senses, e.g., through visual, auditory, and tactile means, improving students' learning and retention of knowledge as a result. Appropriate sites outside of the classroom and school environment are chosen as the setting for outdoor education. Students are assessed over their performances related to the experiments and applications via observations and reports. Generally speaking, outdoor education is not common in Turkey, whereas in specific, at the elementary level, outdoor education seems to be limited to certain social activities and field trips rendered within the scope of student clubs. As Pedretti [1] et al. concluded in their study, the efficiency of outdoor education depends on the teachers. Based on the said study, teachers should be allowed to collaborate with their colleagues to analyze existing outdoor education programs and develop programs of their own. On the other hand, only teachers that are aware of outdoor education ask for such opportunities from the administrative bodies. Therefore, in this study, Turkish classroom teachers' current awareness and perspectives on outdoor education were assessed via descriptive analysis. The specific study group chosen for the study consisted of the classroom teachers working in Şahinbey County of Gaziantep Province. As for collection of the relevant qualitative data, participants were interviewed using a semi-structured interviewing form.
\end{abstract}

Keywords Classroom Teacher, Elementary School, Outdoor Education, Primary School

\section{Introduction}

Education is defined as the process to change one's attitude in an intended direction through one's own experience or one's life [2]. The key word here is 'one's own experience' or 'one's life' implies that educational settings should not be limited only to desks, classrooms, and schools; it has to include real-life environments. In the same lines, outdoor education is defined as a method of experimental learning through all senses via exposure to natural environment $[3,4]$.

Today, it is established that it is not possible to educate the children of age 6 to 12 very efficiently having them sit in the class the entire day. Besides, education cannot be thought independent of the environment as stated by Sobel [5], who claimed that children have to be provided with chances to interact with the environment during the educational process since young ages. Children have the chance through outdoor education to learn through their senses in a relaxed environment. Nature, plants, animals, etc. motivate students to wonder and explore as a result. On the other hand, teachers get to know their students and observe them better in an environment, where the students feel more free and relaxed away from tension acting natural. Maria Montessori [6] supports this idea stating that the goal of contemporary education is to explore and then to liberate the child. Finally Smith suggested that the outdoor education provides the best learning environment [7]. In this regard, many countries in the world have established centers and institutions for outdoor education. These centers train teachers in outdoor education and collaborate with teachers in implementation of outdoor education. They determine the targeted acquisitions and curricular objectives for outdoor education and align the existing curriculum with these objectives. Outdoor Education Australia (OEA) is one of such centers. Turkish government went through a major revision in its educational program in 2005 as many other countries in the world did [8]. Nations expect of their young generation to think creatively and critically forming a contemporary community. Individuals that will form such communities should be aware of what is going on in their surroundings and outdoor education stands out as one of the promising methods to make that happen as Smith points out [9]. 
In his book entitled Emile, Jean Jack Rousseau emphasizes that one of the three most important elements of childhood education is the nature and thus, childhood education cannot be considered independent from nature and environment [8]. Pestallozi and again Rousseau points out the importance of providing education to the children in settings other than the regular classrooms, where they can socially interact $[11,12]$. In the 19 th century, Dewey's idea of "Experimental education" aimed for the students to learn via real life experiences and thus constituted another base for the education that is provided outside of the classroom in general [13]. Dewey considered that children's intrinsic motivation to make physical exercises built more than school-like activities on their learning and development. Pestalozzi supported the idea that children's own endeavors to learn from nature are not sufficient for gaining necessary skills; therefore teachers should introduce natural objects that give children opportunity for sensory experiences [14]. Ideas of the pioneers of the early childhood education, e.g., Rousseau, Pestalozzi, Froebel, and Dewey, all contributed to the idea of outdoor education, emphasizing the positive impact of outdoor environment and activities on children's learning and development $[11,15,16]$. In more contemporary work, it is stated that outdoor environment with its natural unrestricted spaces offers various opportunities to children providing space to move and play so that they can develop different sets of skills $[17,18]$. And in several other studies, it was concluded that the outdoor education had a positive impact on the development of children's skills with regards to time management, social interactions, motivation for success, leadership, emotional control, etc. [19,20,21,22].

Outdoor education addresses all three domains of learning that are, knowledge, skills, and attitudes [23]. Constructivist educational approaches that emphasize the importance of students' self-learning through research and experience suggest outdoor education as well. Outdoor education opens up new horizons for the educators in the context of constructivist educational approach and allows students to be able to express themselves more freely. While doing that, outdoor education does not ignore the fact that each student has a unique way of learning. On the contrary, outdoor education provides students with more opportunities to learn through audio-visual means and through all physical senses in general improving the retention of knowledge in students.

Woodhouse and Knapp claim that outdoor education provides students with experiences that are significant and relevant [24]. Dillon et al. pointed out to the retention levels provided by outdoor education by indicating that students did not forget the outdoor activities they experienced for many long years [22]. Farenga et al. found out that outdoor activities improved students' research skills and increased their academic achievements [25]. Similarly, in his study investigating four different research projects those include outdoor education activities for children, Lien found out that outdoor education improved students in four main areas; personal development, social skills, academic achievements and environmental awareness [26]. Charles J. Eick's [2] study on the effect of outdoor education on the third grade elementary school students revealed an increase in the reading levels of students. Same study also revealed that teachers' minds were opened up to new perspectives. Other studies have also revealed that the students provided with outdoor education turned out to be better in general in terms of self-confidence, concentration, knowledge retention, comprehension; and social, language, communicative, and physical skills.

Regardless of the context, which education is provided, the goals of education all around the world are similar [27]. Shanely suggests that the purpose of outdoor education is to increase the individual's knowledge and awareness about the world that he/she is within and to improve the individual's positive attitude and behavior in general; and states that the scope of outdoor education should not be limited to environmental education but to include courses such as mathematics and even political sciences [12]. Achieving the said objectives of outdoor education depends on the teachers. Therefore, with this study we aim to determine the elementary school teachers' perspectives concerning outdoor education and to find out the limitations that the teachers face in the implementation phase of outdoor education. Furthermore, we aim to promote outdoor education amongst the said teachers considering that the concept of outdoor education is very new in Turkey and thus the related resources are very limited.

\section{Objective of the Study}

In the light of the aforementioned facts, the primary objective of the study is to investigate and determine teachers' perspectives on outdoor education and their tendency and likelihood to employ methods of outdoor education. Secondly, it is also aimed to determine the limitations teachers face in implementation of outdoor education along with detecting teachers' knowledge and awareness about outdoor education via semi-structured interview conducted with 18 elementary school teachers. Study also includes a set of recommendations to educators on how to employ methods of outdoor education and incorporate activities of outdoor education into the existing curriculum in order to improve teachers' awareness and knowledge regarding outdoor education.

\section{Methodology}

Qualitative analysis has been adopted to conduct the study. Semi-structured interviewing form has been used to collect the necessary data. Questions posed in the interviewing form were stimulating and elaborative questions, which aimed to reveal the level of knowledge 
and awareness of the interviewed teachers and whether they implement outdoor education or not along with the reasons in the case they do not. Expert opinions are consulted in the process of preparing the interviewing form. As one of the qualitative analysis techniques, content analysis has been used to analyze the opinions of teachers. Content analysis aims to categorize the collected data that are similar in terms of certain concepts and themes and then to organize and to evaluate them in a manner, which the reader can understand [28]. For this reason, first, seven separate semi-structured interview questions were prepared to detect whether teachers employ outdoor education in their teaching and to reveal the reasons in case they do not. 18 elementary school teachers, with whom the interviews were conducted, were chosen amongst teachers of both private and public schools. The study group comprised teachers of all grade levels of the 4-year elementary school system in Turkey. Thus, teachers of $1 \mathrm{st}, 2 \mathrm{nd}, 3 \mathrm{rd}$, and 4 th grades were included in the study. Following tables display the grade levels that the teachers are teaching, type of school they are working at, and the gender distribution of teachers; respectively.

Table 1. Classification of the Teachers Based on the Grades They Teach

\begin{tabular}{|c|c|}
\hline Grade Level & $\begin{array}{c}\text { \# of Teachers Teaching a Particular Grade } \\
\text { Level (f) }\end{array}$ \\
\hline $1^{\text {st }}$ Grade & 6 \\
\hline $2^{\text {nd }}$ Grade & 4 \\
\hline $3^{\text {rd }}$ Grade & 4 \\
\hline $4^{\text {th }}$ Grade & 4 \\
\hline
\end{tabular}

Table 2. Classification of the Teachers Based on the Type of School They Teach

\begin{tabular}{|c|c|}
\hline School Type & $\begin{array}{c}\text { \# of Teachers Working a Particular Type of } \\
\text { School (f) }\end{array}$ \\
\hline Private School & 6 \\
\hline Public School & 12 \\
\hline
\end{tabular}

Table 3. Classification of the Teachers Based on the Gender

\begin{tabular}{|c|c|}
\hline Gender & \# of Teachers of a Certain Gender (f) \\
\hline Female & 11 \\
\hline Male & 7 \\
\hline
\end{tabular}

\section{Findings}

Major themes designated as a result of pre-evaluation of the answers provided for the semi-structured interview questions were determined as the teachers' levels of knowledge regarding outdoor education; teachers' perspectives of outdoor education in terms of activities rendered; ways of implementing outdoor education that the teachers currently employ; reasons for not employing outdoor education as a teaching technique; contexts of teachers witnessing outdoor education activities rendered; and limitations on employing outdoor education activities; respectively.

\subsection{Teachers' Levels of Knowledge Regarding Outdoor Education}

Primary analysis of teachers' levels of knowledge regarding outdoor education was done in terms of teachers, who have heard of the outdoor education before and teachers, who have not. As a result, it was determined that more than half of the teachers have never heard of outdoor education before. In addition, a secondary analysis revealed that even the teachers, who have heard of outdoor education, did not have sufficient information. Some results are as follows:

Table 4. Classification of the Teachers Based on Their Level Knowledge About Outdoor Education

\begin{tabular}{|c|c|}
\hline $\begin{array}{c}\text { Teachers' Levels of Knowledge Regarding Outdoor } \\
\text { Education }\end{array}$ & $\mathrm{f}$ \\
\hline Teachers, who have heard of outdoor education & 7 \\
\hline Teachers, who have not heard of outdoor education & 11 \\
\hline
\end{tabular}

\subsubsection{Quotes from Teachers, Who Have Heard of Outdoor} Education

"Yes, I have heard of outdoor education. I believe it is a must for the newly installed educational system. Especially subjects that are hard for the children to understand at early ages are better taught via outdoor education." (K3)

"During my first year of teaching in villages, I was teaching drawing and social studies. We did visit traffic training park, zoo, and the chief of village within the scope of these lessons." (K19)

\subsubsection{Quotes from Teachers, Who Have not Heard of} Outdoor Education

"It rings a bell, but I could not tell what it is exactly." (K2)

"I haven't heard of outdoor education before." (K4)

"I haven't heard of outdoor education and I don't know about it." (K14)

\subsection{Teachers' Perspectives of Outdoor Education: Activities that Come Into Their Mind When Told of Outdoor Education}

Teachers have responded to the semi-structured interview questions giving examples of what they understand from outdoor education in terms of activities rendered as shown in Table 5.

Table 5. Ways of Implementing Outdoor Education that the Interviewed Teachers Employ

\begin{tabular}{|c|c|}
\hline $\begin{array}{c}\text { Ways of Implementing Outdoor Education That the } \\
\text { Interviewed Teachers Employ }\end{array}$ & $\mathrm{f}$ \\
\hline Activities out of School/Class & 13 \\
\hline Field Trips & 2 \\
\hline Fun activities, games & 1 \\
\hline Activities, in which students move freely in the classroom & 1 \\
\hline Complimentary/Supplementary activities & 1 \\
\hline
\end{tabular}




\subsubsection{Quotes from Teachers Regarding Outdoor Education} and Associated Activities

a) Activities out of School/Class

Most of the interviewed teachers mentioned of activities out of school/class regarding outdoor education. Examples of such quotes are as follows;

"Education should not be just limited to the classroom. Many places outside of the classroom may be appropriate to render educational activities."(K1)

"Just going to garden with students even is an example of the outdoor education." (K8)

"Outdoor education brings out of the classroom into mind. Garden may be such a place."(K14)

"Outdoor education is fun for students and a good thing for me in terms of students' comprehension." (K18)

\section{b) Field Trips}

"We used to name such activities as trips, which are called outdoor education activities, now."(K 13)

"I suppose outdoor education has something to do with taking students on a trip or to a park. An example in our city may be to take them to the Planetarium."(K16)

c) Fun Activities\&Games

"Outdoor education is fun for students and a good thing for me in terms of students' comprehension." (K18)

d) Activities, in Which Students Move Freely in the Classroom

"Independent activities, in which students generally use internet comes to mind when thinking of activities, in which students move freely in the classroom."(K11)

e) Complimentary/Supplementary Activities

"Complimentary/supplementary activities may reinforce students leading to retention of knowledge. Besides, teachers become more consistent and integral in their profession" (K10)

\subsection{Ways of Implementing Outdoor Education That the Interviewed Teachers Employ}

Teachers' answers to the interview questions were categorized into groups of teachers that do employ outdoor education activities and teachers that do not. The ones that do employ outdoor education activities mentioned of field trips to museums, factories, supermarkets, meteorological institutions, natural sites; family visits/homevisits; and student performances/displays.

Table 6. Whether Teachers Employ Outdoor Education Activities or Not

\begin{tabular}{|c|c|}
\hline $\begin{array}{c}\text { Whether Teachers Employ Outdoor Education Activities or } \\
\text { not }\end{array}$ & $\mathrm{f}$ \\
\hline The ones that do not employ outdoor education activities & 6 \\
\hline The ones that do employ outdoor education activities & 12 \\
\hline
\end{tabular}

\subsubsection{Quotes from Teachers That Do Not Employ Outdoor Education Activities}

"It is very rare that I have employed outdoor education activities despite the fact that our garden is suitable for such activities. I suppose it is our laziness that is the problem" (K1)

"No, I don’t employ outdoor education activities!" (K10), (K12), (K15)

"I haven't able to employ outdoor education activities until now due to lack of facilities and opportunities in general." (K17)

Table 7. Types of Outdoor Education Activities Teachers Employ

\begin{tabular}{|c|c|}
\hline Types of Outdoor Education Activities Teachers Employ & $\mathrm{f}$ \\
\hline Field trips to natural sites & 6 \\
\hline Field trips to museums & 3 \\
\hline Field trips to supermarkets & 3 \\
\hline Field trips to factories/plants & 2 \\
\hline Field trips to governmental institutions & 2 \\
\hline Family visits/home visits & 1 \\
\hline Student performances/displays & 1 \\
\hline
\end{tabular}

4.3.2. Quotes from Teachers That Employ Outdoor Education Activities

a) Field Trips to Natural Sites

"We have outdoor education activities that serve as science acquisitions in the garden or laboratory."(K6) "I took students to the garden when teaching them rock and soil formation. There were small rocks in the school garden and around the school. This way, I tried to teach them the formation of rocks and soil as much as I can." (K8)

"We had a trip with students to a natural site last year, where students had the chance to check out the plants and animals first hand....under rocks, everywhere...."(K11)

"We had an ourdoor education activity with students of 4th and 5th grades teaching them refraction of sun light. " (K14)

"We had a trip last year with students of 4th and 5th grades within the social studies course. The trip was about the landforms. We took them to mountains, villages, lakes, and to a river nearby the school." (K16)

b) Field Trips to Museums

"We did go to museums with students." (K11)

"I took students to museums such as Zeugma Mosaic Museum, planetarium, botanic garden, central library, Museum of Turkish Independence War, etc.” (K19)

c) Field Trips to Supermarkets

"We try to take the students to places like factories, supermarkets, etc. in the framework of Production-Consumption-Efficiency unit." (K3)

"We take students of $1^{\text {st }}$ grade to the supermarket to 
teach them about shopping and spending right." (K4)

d) Field Trips to Factories/Plants

"Examples to the trips we had are; trip to the zoo, to the chocolate factory, to the library, to the nursery garden trip, etc." (K3)

"We try to take the students to places like factories, supermarkets, etc. in the framework of Production-Consumption-Efficiency unit.” (K3)

e) Field Trips to Governmental Institutions "We have activities such as taking students to meteorological institutions when learning about the weathercast topic of social studies course." (K5)

"We generally have trips in relation to the acquisitions of the social studies course. Trips to the Directorate of Civil Registry, regional healthcare centers, municipality, supermarkets are such examples." (K6)

"We have trips for students of 4th and 5th grades regarding the concept of meteorology." (K8)

"We take students to meteorological institutions." (K9)

f) Family Visits/Homevisits

"I suppose family visits/home visits would count as outdoor education activities as well." (K7)

g) Student Performances/Displays

"We had a big student performance event outside of the school. We prepared all students to this event." (K8)

\subsection{Teachers' Reasons for not Employing Outdoor Education as a Teaching Technique}

Some of the interviewed teachers have responded negatively to questions, in which they were asked whether they employ outdoor education practices or not. When they were asked of the reasons why they were not implementing outdoor education, they stated reasons such as having limited time, too crowded classes, lack of necessary information about outdoor education, laziness, and concerns about meeting curricular deadlines. Table 8 summarizes the reasons stated by teachers.

Table 8. Teachers' Reasons for not Employing Outdoor Education

\begin{tabular}{|c|c|}
\hline Teachers' Reasons for not Employing Outdoor Education & $\mathrm{f}$ \\
\hline Large class sizes & 6 \\
\hline Laziness & 4 \\
\hline Concerns regarding meeting curricular deadlines & 3 \\
\hline Limited time & 2 \\
\hline Lack of information about outdoor education & 1 \\
\hline
\end{tabular}

4.4.1. Quotes from Teachers That Stated a Reason for Not Employing Outdoor Education Activities

a) Large Class Size
"Class sizes must be reduced down to 20 to 25 students. It would be a lot easier to take this many students on a field trip renting only a single shuttle."(K8)

"...but classes are so crowded. There is an average of 40 to 45 students in each class." (K12)

"It is really hard to organize a field trip with crowded classes." (K13)

"The classroom size is a risk!" (K16)

b) Laziness

"In fact our garden is really big and suitable for outdoor activities. However, I suppose we are too lazy." (K1)

"Traditional methods have become habits. It is difficult to adopt a new method." (K10)

"...I think it is a little bit because of laziness as well. Sometimes there are also safety concerns. There are also topics that we have to cover in a timely manner. Sometimes, it takes a whole day on a field trip, so convince ourselves to stay inside and teach more lessons." (K11)

"We do try, however we dread against difficulties and hence we may ignore the things that we have to do." (K15)

c) Concerns Regarding Meeting Curricular Deadlines "Curriculum keeps changing all the time. Books require many different activities. Our parents used to have books of many different publishers. When the units we teach and the parents think of, do not match, they complain about non-compliance and blame the teachers for not teaching certain topics included in the books of other publishers. Therefore, we prioritize curriculum and most of the time finish curriculum earlier than we are supposed to do so.” (K1)

Table 9. Whether Teachers Have Witnessed Outdoor Education Activities or Not

\begin{tabular}{|c|c|}
\hline $\begin{array}{c}\text { Whether Teachers Have Witnessed Outdoor Education } \\
\text { Activities or Not }\end{array}$ & $\mathrm{f}$ \\
\hline $\begin{array}{c}\text { Teachers who have not witnessed outdoor education } \\
\text { activities }\end{array}$ & 6 \\
\hline Teachers who have witnessed outdoor education activities & 12 \\
\hline
\end{tabular}

"...I wish there was more time and less curricular objectives to meet...We are mandated to cover the theory in class, otherwise we are questioned by our supervisors"(K2)

"We have units that we have to finish."(K11)

d) Limited Time

"Limited time and curriculum are the problems."(K1)

"Limited time is really a big problem."(K2)

"...I wish there was more time and less curricular objectives to meet...We are mandated to cover the theory in class, otherwise we are questioned by our supervisors"(K2)

"...There are also topics that we have to cover in a 
timely manner. Sometimes, it takes a whole day on a field trip, so convince ourselves to stay inside and teach more lessons." (K11)

e) Lack of Information About Outdoor Education "I do not know much about outdoor education really.”(K18)

\subsection{Contexts of Teachers Witnessing Outdoor Education Activities Rendered}

Teachers, who were interviewed, were categorized into two groups of teachers that saw outdoor education activities before and the ones that did not as shown in Table 9.

\subsubsection{Quotes from Teachers Who Have Not Witnessed or} Seen Outdoor Education Activities

Table 10. Contexts that the Teachers Have Witnessed Outdoor Education Activities

\begin{tabular}{|c|c|}
\hline $\begin{array}{c}\text { Contexts that the teachers have witnessed outdoor education } \\
\text { activities }\end{array}$ & f \\
\hline Traffic training park & 3 \\
\hline Zoo & 2 \\
\hline Mathematics course & 2 \\
\hline English course & 1 \\
\hline Geography course & 1 \\
\hline
\end{tabular}

"I haven't witnessed any outdoor education activity where I work at, probably because this is only my first year as a teacher." (K4)

"I haven't seen any outdoor education activity, but I have heard that it is done abroad. They are examining animals for instance. They take students to the zoo. They take them to the market and teach them about shopping." (K10)

"I have not seen as an example before; however sometimes students are taken to the park adjacent to the school and they are allowed to play both soccer and basketball.” (K16)

\subsubsection{Quotes from Teachers Who Have Witnessed or Seen Outdoor Education Activities}

Based on the answers provided to the semi-structured interview questions, contexts, which the teachers have seen or witnessed outdoor education activities are categorized into five groups of zoo, traffic training park, math, English, and geography courses; respectively, as shown in Table 10.

a) In the Context of Traffic Training Park

"I surely did witness outdoor education activities. I took my own students on an outdoor educational activity as well. There were cars running on batteries, and the policemen took good care of us." (K15)

"I have heard of outdoor education in the context of going to zoo, traffic training park, and chief of village." (K18)

b) In the Context of Zoo
"Examples to the trips we had are; trip to the zoo, to the chocolate factory, to the library, to the nursery garden trip, etc." (K3)

c) In the Context of Math Course

"for instance we often go outside to measure the height and length of the wall within the framework of the unit regarding measure of length in the math course." (K5)

"Math teachers in our school organized an outdoor activity to measure the size of the school's shadow." (K6)

d) In the Context of English Course

"English teachers in our school organized an outdoor treasure hunt activity. They were giving hints and clues to students allowing them to find the treasures hidden out of the classroom." (K6)

e) In the Context of Geography Course

"Outdoor education activities are rendered especially in geography classes when teaching of plants, landforms, etc. I have seen my colleagues organizing such activities." (K14)

\subsection{Limitations on the Implementation of Outdoor Education Activities}

Limitations on employing outdoor education activities that the teachers face are categorized into themes of crowded classes, difficulty in transportation to the site, hardship in getting official permissions, excessive teacher workload, rigid school administrations, and time limitations.

Table 11. Limitations on the Implementation of Outdoor Education Activities

\begin{tabular}{|c|c|}
\hline Limitations on Employing Outdoor Education Activities & f \\
\hline Crowded classes & 6 \\
\hline Difficulty in transportation to the site & 6 \\
\hline Hardship in getting official permissions & 6 \\
\hline Excessive teacher workload & 2 \\
\hline Rigid school administrations & 1 \\
\hline Time limitations & 1 \\
\hline
\end{tabular}

4.6.1. Quotes from Teachers Who Mentioned of the Limitations They Face in Implementation of Outdoor Education Activities

a) Crowded Classes

"There may be difficulties in implementation of outdoor education activities due to crowded classes." (K6)

"It is really hard to maintain control in crowded classes. There are too many involved risks. Besides, students are easily distracted when at outdoors." (K14) "Classes are so crowded, so it gets really hard to 
contain them outdoors." (K15)

"I have 43 students in my class and it gets very difficult to look after them.” (K18)

b) Difficulty in Transportation to the Site

"...We face problems regarding field trips out of the city in terms of transportation and getting permission."(K7)

"We use shuttle services or buses provided to us by the city when going on field trips. However, the buses get very crowded. The drivers are usually careless and drive very fast; thus we have to require references."(K15)

"Crowded classes and shuttle service opportunities are the problems we face."(K17)

c) Hardship in Getting Official Permissions

Teachers face hardships when trying to obtain permission from the parents and the administrative permission.

i. Permission from Parents

"Parents' permission must be obtained. It is also difficult to handle first graders."(K4)

"Some of our parents may not give permission. They have their reasons." (K15)

"Getting permission from parents is hard when it comes to trips. There are also risks involved." (K17)

\section{ii. Administrative Permission}

"Our biggest problem is getting permission from the school administration and from the places to be visited." (K15)

\section{d) Excessive Teacher Workload}

"We have to manage certain procedures and handle the related paperwork, getting permissions, writing official letters, photocopies, etc." (K15)

"We do try, however we dread against difficulties and hence we may ignore the things that we have to do. We have to deal with all the paperwork on our own" (K15)

e) Rigid School Administrations

"School administration must be very effective. For example, if the administration considers you wasting the class time, when you are actually implementing an outdoor education activity such as planting saplings or having breakfast in the garden, it is a problem." (K1)

\section{f) Time Limitations}

"The problem really is the time. I wish everybody were recommending outdoor education rather than just talking about it...I wish the curriculum was more aligned with outdoor education...Official procedures get in the way postponing students."(K2)
In this study, elementary school teachers' view of outdoor education, ways of implementing outdoor education and reasons for not employing outdoor education have been investigated. In the light of the collected data, teachers' levels of knowledge about outdoor education have been investigated and answer to the question, "what does outdoor education mean for the teachers?" has been sought for. Following conclusions are derived based on the analyzed data:

1. When teachers were asked about their knowledge about outdoor education, it was observed that two thirds of the interviewed teachers have never heard of outdoor education before. When teachers were asked about what outdoor education means to them, they usually responded with vague answers just predicting that it is education outdoors; which was a result that has been predicted by the researchers of the study in advance as the concept of outdoor education is fairly new in Turkey. Some of the participants sorted the educational activities they do; however, they did not know exactly whether these activities could be considered within the scope of outdoor education or not. Pedretti et al. pointed out to the same fact [1] and Eick [2] stated that it is the teachers' awareness about outdoor education, which will make this educational approach a success. Therefore, it can be concluded that outdoor education is not successfully employed considering the interviewed teachers' lack of knowledge about outdoor education.

2. Teachers that employ outdoor education were found to be more than the teachers that were not. However, the effectiveness and efficiency of the implemented outdoor education activities were quite low due to lack of knowledge about outdoor education in general. It was observed that teachers wrongfully tend to think that outdoor education is just a matter of practice and there is no theoretical background to it. This result suggests that the teachers that try to utilize outdoor education as a teaching method make an attempt to be successful within their own capacity and without any external support. Similar results were also obtained by Carrier, Moseley et al., Orion et al., Wagner et al., and Smith et al. [29, 30, 31, 32, 33], whereas Simmons [34] found out that the teachers felt insufficient with respect to outdoor education in general.

3. When the types of outdoor education activities are considered, it was observed that field trips to natural sites take the lead. This is a good sign as integration with the nature is one of the main objectives of the outdoor education and leads to better comprehension in students as stated by Eick [2]. However, the necessity to enrich the types of the sites to be visited still stands as it is not just the wild nature that can provide significant experience but also the science museums, aquariums, botanical

\section{Discussion and Conclusions}


gardens, forests, natural centers, zoos, museums, aqua parks, playgrounds, youth centers, beaches, stadiums, hospitals, civic organizations etc. as detailed in the studies of Fadigan et al. [27] and Bozdogan [35], which have been cited to have positive impact on children's development [36].

4. Analysis of the contexts that the teachers witnessed outdoor education revealed that teachers have seen these activities or they have witnessed these activities in person usually at the school they work. Witnessed activities were trips to the zoos, traffic training parks, and other outdoor activities commonly within the scope of math, English, and geography classes.

5. An important percentage of the teachers stated to have rarely employed outdoor education and they list a number of reasons for that. One of the reasons stated for not employing outdoor education activities are the crowded classes, which concern teachers in terms of safety and security. Crowded classes are more common in public schools leading teachers, who avoid the risks associated with outdoor education activities, to stay inside to maintain control. Another reason was the concern in meeting the curricular deadlines. An intense curriculum and limited time is a major reason why teachers avoid spending even one day outside. Difficulties in transportation turn out to be another reason. Teachers tend to refrain themselves from facing the risks involved with taking students from one place to another via shuttle services. Parents hesitating to grant permission for their children to participate in the outdoor education activities constitute another reason. It is important to get parents' support to effectively implement outdoor education as Tatar et al. indicated [37]. Similar reasons were also cited in Thomas' study [38]. All of these aforementioned reasons seem to lead teachers to refrain themselves from outdoor education and continue with the traditional educational approaches. As a result, outdoor education activities are limited to the framework of field trips commonly rendered once a semester if not less.

6. Teachers seemed not to tend to outdoor education assuming that they will never be able to employ outdoor education as a major educational approach due to the existing physical conditions and the lack of facilities. However, it also seems that teachers' lack of information about outdoor education also triggered teachers to list some irrelevant reasons. Hence, more research is needed to close the gap between the teachers' theoretical knowledge about the outdoor education and what they really do in practice as also indicated in the work of Pedretti et al. [1], which would also help developing new pedagogical strategies that are aligned with outdoor education.

\section{Recommendations}

Following are the recommendations suggested to increase teachers' awareness, interest, and information regarding outdoor education and to improve the facilities teachers need to employ outdoor education:

1. Centers for Outdoor Education may be established in the capacity of Ministry of Education taking existing outdoor education centers abroad as models. Experts specifically working on outdoor education could be employed at these centers. These centers may periodically inform and update primarily school administrators, teachers, secondarily students, and parents about outdoor education. Such centers may demonstrate sample activities rendered domestically and abroad promoting outdoor education opening up new horizons for anybody involved with education. This way, teachers could be made aware of outdoor education and obstacles that emanate from administrators and parents in implementation of outdoor education may be prevented to some extent.

2. If outdoor education activities could be directly incorporated into the curriculum, then teachers' concerns about not meeting curricular deadlines when implementing outdoor education activities could be rendered useless.

3. Problem of having crowded classes making implementation of outdoor education activities can be easen up with the help of a second or third invigilator besides the classroom teacher. Parents volunteering for assistance could be utilized.

4. Existing procedures and regulations may be reviewed with respect to the required permissions and security matters to facilitate outdoor education.

\section{Acknowledgements}

We are very grateful to both Zirve University of Turkey and International Zaman University of Cambodia for their willingness to support us during our studies.

\section{REFERENCES}

[1] Pedretti, E.; Nazir, J.; Tan, M.; Bellomo, K.; Ayyavoo, G. A Baseline Study of Ontario Teachers' Views of Environmental and Outdoor Education. The Ontario Journal of Outdoor Education, volume:24 (2) p. 4-12 winter. 2012.

[2] Eick, C. Use of the Outdoor Clasroom and Nature-Study to Support Science and Literacy Learning: A Narrative Case Study of a Third-Grade Clasroom. Journal of Science Science Teacher Education, volume: 23 (7) p. 789-803, 2011. DOI:10.1007/s10972-011-9236-1.

[3] Lund, P. M.; Gaigher R. A Health Intervention Programme for Children with Albinism At a Special School in South Africa. Health Education Research. Oxford University Press. 2002. 
[4] Priest, S. Redefining Outdoor Education: A Matter of Many Relationships. Journal of Environmental Education Volume:17 (3) p.13-15. 1986.

[5] Sobel, D. Sense of Place Education for the Elementary Years. Prooceedings of the 1997 Forum.p. 32-39. ERIC Document Reproduction Service No. ED421312. 1997.

[6] Montessori, M. Childhood Education. Canadian Family Physician, 137 p.17, 1975. DOI: 10.1080/00221473.1955.10 630814.

[7] Smith, J. Outdoor Education and Youth.Washington,DC: American Association for Health ,Physical Education and Recreation. 1955.

[8] Ertürk, S. Program Development in Education, Ankara:Meteksan Co., Ltd. 1979.

[9] Smith, J. Outdoor Education and Youth.Washington,DC: American Association for Health ,Physical Education and Recreation. 1955.

[10] Oktay, A. Magical Years of Life. İstanbul. Epsilon Publishing. 1999.

[11] Powers, D. L. The effects of an outdoor education program on life effectiveness skills of participant. Master of Science Thesis, California State University, USA. 2004.

[12] Shanely, S. D. Towards an understanding of an outdoor education program: Listening to participants' stories. PhD Thesis, University of Florida, USA. 2006.

[13] Dewey, J. Experience and nature. LaSalle, IL: Open Court. 1889.

[14] Wellhousen, K. Outdoor play every day: Innovative concepts for early childhood. Albany, NY: Delmar. 2002.

[15] Tsai, J.T. The identification of the components for an outdoor education curriculum in Taiwan. $\mathrm{PhD}$ Thesis, Indiana University, USA. 2006.

[16] Wolfgang, C. H. Child guidance through play: Teaching positive social behaviors. Boston: Pearson Education. 2004.

[17] Bilton, H. Outdoor play in the early years. London: David Fulton. 2002.

[18] Rivkin, M. The great outdoors: Restoring children's right to play outside. Washington, DC: National Association for the Education of Young Children. 1995.

[19] Carrier, A. M. The emergence of democratic educational and experiential educational philosophies in the practice of outdoor education. Master of Art Thesis, University of Toronto, Canada. 2004.

[20] Miller, T. J. The Alaska factor: Outdoor education program design in Alaska. Master of Education Thesis, University of Alaska, USA. 2008.

[21] Murdock, M. L. Outdoor education as a protective school-based intervention for "at-risk" youth: A case study examining the muskoka woods leadership experience for "students of promise" program. PhD Thesis, University of Windsor, Ontario, Canada. 2007.

[22] Dillon J., Rickinson, M., Teamey, K., Morris, M., Choi, M. Y., Sanders, D. \& Benefield, P. The value of outdoor learning: evidence from research in the UK and elsewhere. School
Science Review, 87 (320), 107-111. 2006.

[23] Ford, P. M. Principles and Practices of Outdor/Environmental Education. Wiley Co. NY. 1981.

[24] Woodhouse, J. L.; Knapp, C. E. Place-Based Curriculum and Instruction: Outdoor and Environmental Education Approaches. ERIC Clearinghouse on Rural Education and Small Schools Charleston WV. 2000.

[25] Farenga, S.; Joyce, B. Development and analysis of a scale to assess students' out-ofschool science-related experiences. Education, 118. 1998.

[26] Lien, H. A. "The Benefits of Outdoor Education Experiences on Today's Youth. " Paper presented at the annual meeting of the North American Association For Environmental Education, Virginia Beach Convention Center, Virginia. 2007.

[27] Fadigan, K. A.; Hammrich, P. L. A longitudinal study of the educational and career trajectories of female participants of an urban informal science education program. Journal of Research in Science Teaching, 4, 8, 835- 860. 2004.

[28] Yıldırım, A. ve Şimşek, H. (2006). Sosyal bilimlerde nitel araştırma yöntemleri. Ankara: Seçkin Yayınevi

[29] Carrier, S. J. The effects of outdoor science lessons with elementary school students on preservice teachers' self-efficacy. Journal of Elementary Science Education,21(2),35-48. 2009.

[30] Moseley, C., Reinke, K. Bookout, V. The effect of teaching outdoor environmental education on preservice teachers' attitudes toward self-eff icacy and outcome expectancy. The Journal of Environmental Education, 34(1), 9-15. 2002.

[31] Orion, N., Hofstein, A.,Tamir, P., Giddings, G. J. Devolopment and validation of an instrument for assesing the learning environment of outdoor science activities. Science Education, 81, 161-171. 1997.

[32] Wagner, C. \& Gordon, D. (2010). "Planning school grounds for outdoor learning." National Clearinghouse for Educational Facilities at the National Institute of Building Sciences, 1-7. [Online] Retrieved on 24-April-2011, at URL:http://cherylcorson.com/pdfs/outdoorlearning.pdf

[33] Smith-Sebasto, N. J. \& Smith, T. L. (1997). Environmental education in Illinois and Wisconsin: A tale of two s tates. Journal of Environmental Education, 28 (4), 26-36.

[34] Simmons, D. Using natural settings for environmental education: Perceived benefits and barriers. Journal of Environmental Education, 29 (3), 23-31. 1998.

[35] Bozdogan, A. E. Bilim ve teknoloji müzelerinin fen öğretimindeki yeri ve önemi. Doktora Tezi, Gazi Üniversitesi, Eğitim Bilimleri Enstitüsü. 2007.

[36] Türkmen, H. Informal sınıf dışı fen bilgisi eğitimine tarihsel bakış ve eğitimimize entegrasyonu. Çukurova Üniversitesi Eğitim Fakültesi Dergisi, 3 (39), 46-59. 2010.

[37] Tatar, N. Bağrıyanık, K. E. Opinions of Science and Technology Teachers about Outdoor Education Elementary Education Online, 11(4), 883-896. 2012.

[38] Thomas, G. Facilitator, teacher, or leader? Managing conflicting roles in outdoor education. Journal of Experiential Education, 32(3), 239-254. 2010. 